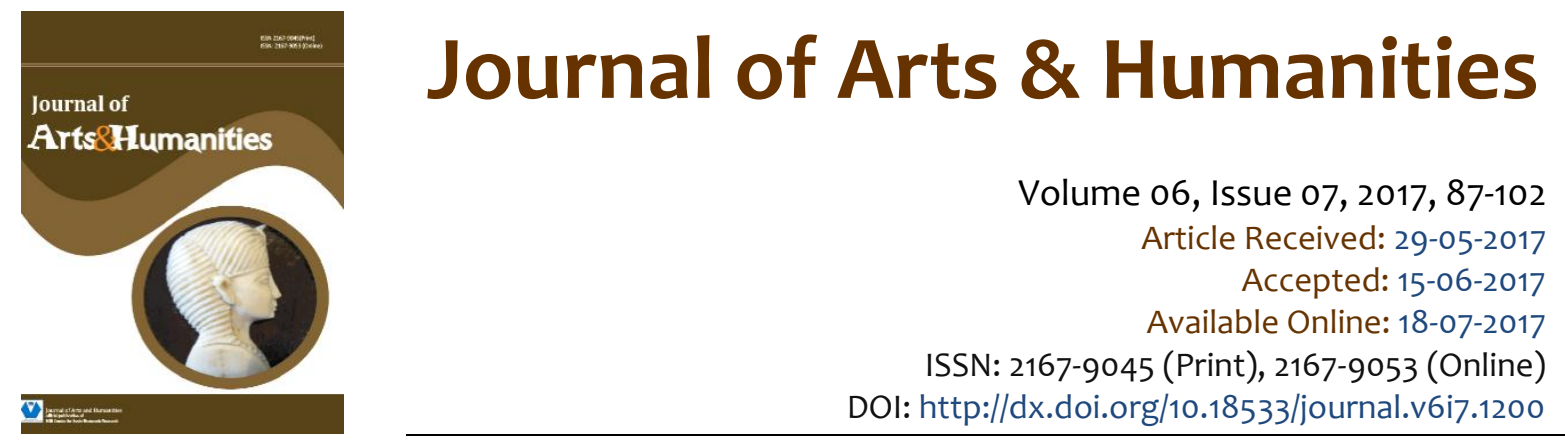

\title{
On Telling a Lie to Reveal the Truth: Mongrel
}

\author{
J.C. Oleson ${ }^{1}$
}

\begin{abstract}
South African author William Dicey's 2016 collection of essays, Mongrel, operates as a literary prism, refracting and clarifying literary and sociological elements of life. The book's six essays grapple with a sprawling range of subjects, including: the elusive distinction between fiction and non-fiction, literary footnotes, the endeavor of writing, the search for truth, the citizen's search for community, the relevance of ethnicity in post-apartheid society, the perpetuation of socioeconomic disadvantage, the tragedy of criminal justice, and collective moral culpability for climate change. History, economics, and practical ethics underscore the entire collection, and exogenous sources such as Nabokov's Pale Fire and Coetzee's Disgrace can lend depth to the works. The essays of Mongrel can be understood as six discrete works, but they can also be understood as a meta-narrative that takes as its object the sociological search for restored community and the literary quest for authenticity.
\end{abstract}

Keywords: Apartheid, Climate Change, Community, Dicey, Ethnicity, South Africa.

JEL Codes: D63, K42, N37, Q54, Y30

This is an open access article under Creative Commons Attribution 4.0 License.

\section{Introduction}

The essay, as a Western literary form, is typically attributed to Michel de Montaigne (1588/1958) and its earliest examples, in English, are associated with Francis Bacon (1597/1985) (Gualtieri, 2008). These early authors paved the way for subsequent, iconic works such as "Common Sense" (Paine, 1776), "A Modest Proposal" (Swift, 1729), "Self-Reliance" (Emerson, 1841/1907), and "On the Duty of Civil Disobedience" (Thoreau, 1849).

However, the essay, as literary expression, typically focuses upon substance over form. It is often the underlying idea, not the language that conveys that idea, which matters. The notion of creative nonfiction - of essays that employ expressive, crafted prose to communicate their ideas - is of relatively recent vintage (Lounsberry, 1990). But one of the rules of creative nonfiction is that the account must be factual:

\footnotetext{
${ }^{1}$ Associate Professor of Criminology, Sociology, University of Auckland, Auckland 1142 New Zealand. Tel: 6493737599 x84522, Fax: 649373 7439, E-mail: j.oleson@auckland.ac.nz
} 
"Creative" doesn't mean inventing what didn't happen, reporting and describing what wasn't there. It doesn't mean that the writer has a license to lie. The cardinal rule is clear-and cannot be violated. This is the pledge the writer makes to the reader - the maxim we live by, the anchor of creative nonfiction: "You can't make this stuff up!" (Gutkind, n.d.).

The boundaries between fiction and non-fiction, between fact and falsehood, however, are far less defined than readers (or library shelves) typically acknowledge. All writing - even the most rigorously factual report - involves a selective accounting of events, and every writer necessarily tells part of his or her story while omitting countless other potential pieces. Conversely, fiction regularly draws upon real events, on real human experiences, distilling them so as to produce a superior narrative.

The uneasy boundaries between fiction and fact are explored in a recent collection of essays, Mongrel, by the South African author, William Dicey (2016). In Mongrel, Dicey combines fact and apparent fact to scrutinize the search for authenticity across both literary and sociological topics. Examining a variety of subjects that span apartheid, climate change, homicide trials, as well as the contested boundaries between fact and fiction, Dicey's book makes for a challenging and provocative read; the essays in Mongrel, however, are even more compelling when they are read in the light of external, exogenous sources. This approach was adopted when conducting the current analysis. First, each essay was read carefully and in full; second, key concepts and themes were identified within the text of the essay; third, external scholarship was consulted in order to shed additional light on the essay; and fourth, the essay was re-read in light of the additional sources.

This methodology of iterative reading allowed the author to establish linkages between Dicey's essays and a wider research literature. This article describes some of the key themes that emerged in Dicey's essays and describes their relationships to the wider, relevant scholarship. In this way, the current article makes modest contributions to research on social responses to climate change, socioeconomic dimensions of colonialism, comparative criminal law and criminal procedure, traditions of citation in academic writing and fiction, and the study of the writing process.

Mongrel consists of six discrete essays. The first to appear in the book, "Miss Meat Festival," is a gonzo portrait of the Hantam Festival in Calvinia, a rural sheep farming community. The second, "A Story in Which Everyone Looks Bad," is a murder mystery, and a searing critique of the criminal justice system. The third, "South African Pastoral," is a social history of the expenses associated with Dicey's farm. The fourth, "No Ship Exists," is a book review of kinds, and a travelogue of India. The fifth, "What Goes on Inside Is Just Too Fast," is a book review essay, exploring linkages between three works of fiction. And Dicey's sixth essay, "D'Arcy and I," is a Borges-like description of the novels of Michael D'Arcy. After a brief description of the analytical method followed in the study, each of the six essays is discussed in a section of this article. They are not described in the sequence they appear in Dicey's book, but as they relate to the researcher's interests. The article concludes with a brief discussion of the cross-cutting themes in the essays, and identifies some of the implications of Dicey's work.

\section{Methodology}

Certainly, it would be possible to analyze a collection of texts using quantitative techniques, such as computing the number of paragraphs, or the relative frequencies of recurring terms (such as the analyses that underlie word cloud visualizations of a text). But such a quantitative approach would reveal little about the meaning of the words. Nor could this approach read between the lines, noting what is latent but left unsaid. In order to grapple with the meaning of Dicey's essays, rather than their composition, a qualitative analysis of Dicey's essays was required (Bryman, 1988).

The approach followed in the current research resembled, in some respects, the social science technique of thematic analysis (Braun \& Clarke, 2006). But it differed from traditional thematic analysis in that the ultimate goal was not to identify themes within the data, but to tease out themes in order to link these 
to exogenous pieces of scholarship and to consider whether and how that changed the reading of the essay.

For each of Dicey's six essays, the first step involved reading the work carefully. No notes were taken during this reading, and no external sources were consulted. The second step involved the identification of key themes. Often, these were semantic and were apparent in the text, such as when Dicey recounts his response to Derrick Jensen's book, Endgame (2006a). Sometimes, however, they were latent, such as when Dicey reports sundry farming expenses, but the underlying narrative is actually about race relations in post-apartheid South Africa. Notes were taken in this stage, key words were identified, and questions were framed. In the third stage, exogenous sources - novels, poems, essays, as well as social science and legal scholarship - were consulted, where Dicey's essays seemed to be related. Notes were taken on these external sources. Then, finally, in the fourth stage, the essays were re-read in light of the additional sources. The researcher asked whether the additional sources changed the understanding of the essay.

\section{No ship exists}

A decade ago, I published an article about the legal ramifications of climate change (Oleson, 2007a). That article begins with a set of linked questions: "[l]f you could travel back in time, would you kill the struggling watercolor artist Adolf Hitler in order to avert the Holocaust? If it could prevent a looming nuclear apocalypse, would you murder an innocent scientist? Would you murder a president?" (p. 19). These questions, of course, are variations on the famous trolley problem of utilitarian ethics (Foot, 1967). The article moves from the introductory questions and outlines three examples - Tyler Durden from Fight Club (Palahniuk, 1996), Unabomber Theodore Kaczynski, and Oklahoma City Bomber Timothy McVeigh in order to frame a hypothetical (i.e., a climate activist and his co-conspirators shut down electrical grids, bomb facilities that attempt to restore operations, and then turn themselves in so as to articulate a criminal defense of climate necessity).

In part, my article was an attempt to work though some of the arguments laid out in Derrick Jensen's vexing book, Endgame (2006a). Endgame is a scathing jeremiad about humankind's willful ignorance in the midst of ecological catastrophe. In his book, Jensen couples a powerful critique of human civilization with a Luddite call to direct, revolutionary action. The argument makes for uncomfortable reading, like the red pill from The Matrix (Wachowski \& Wachowski, 1999), and my own article was an attempt to unpack some of the book's implications. Writing the article was my bid for catharsis, although it was unlikely to change the direction of climate change. After all, the average number of citations for a singleauthored law article is a whopping two (Bastow, Dunleavy, \& Tinkler, 2014). Thus, when a friend from graduate school shared an essay that another one of his friends had written, I was stunned to see that someone had actually read (and even referenced) my article. But what really gripped me about the essay was that its author also had gone on to read Endgame, and that he, too, had been affected, disturbed, and possibly damaged by the terrific virulence of Jensen's work.

William Dicey's essay, “No Ship Exists," describes his agonizing over Endgame's twenty core premises ("Civilization is not and can never be sustainable. This is especially true for industrial civilization" [Jensen, 2006a, p. ix]) and its Luddite conclusions. Jensen's arguments lodged in Dicey's mind and festered there, as they had in my own. However, Dicey, who had studied engineering and who had earned his MPhil in Environment and Development, buckled under the force of Jensen's argument. Dicey could not exorcise his demons merely by writing an article. Instead, Dicey took the extraordinary step of uprooting himself and traveling to India. "My life ground to a halt. I was divided, paralysed, unable to perform the simplest of actions. After months of lassitude, my only hope of recovery, it seemed, lay in doing something drastic. I decided to go to the Himalayas" (Dicey, 2016, p. 132).

Proust (1993) famously observed that the real voyage of discovery consists not in seeking new landscapes but in having new eyes. In India, William Dicey struggled to understand Jensen in another light. He stayed on a houseboat on Dal Lake, lodged in a series of guesthouses, and trekked through 
mountains. He watched arthouse films, read old magazines, and practiced yoga. Dicey hoped that, in India, he might escape from Jensen, but he could not.

There's an internal logic to Jensen's arguments he seldom, if ever, lets slip. This made for an uncomfortable predicament. I agreed with his critique of industrial society, yet I baulked at his casual endorsement of violence. So seamless, though, was his transition from the critique to the violence that I couldn't see where to part ways with him (Dicey, 2016, p. 140).

Therein lies the power of Jensen's Endgame. If you accept Jensen's premises (and it is difficult for persons with any measure of cynicism about human nature to not accept them, at least most of them), then it is difficult to avoid reaching his conclusions. To his credit, Dicey struggled to locate the chink in Jensen's armor. He sought out critiques of Jensen and Jensen's work, ranging from the ad hominem (e.g., a characterization of Jensen's writing as "vomit on the page") to more thoughtful rebuttals (e.g., the observation that when you return man to the state of nature, you don't get a beautiful Rousseau-inspired noble savage; you get Hobbes: "roving bands of youths with guns, raping and killing and eating whatever they find" [Dicey, 2016, p. 144]). But these critiques could not solve Dicey's dilemma: for he had accepted Jensen's diagnosis of the problem (i.e., civilization is unsustainable), yet he could not stomach Jensen's prescription (i.e., civilization therefore must be destroyed). The cognitive dissonance must have been terrible.

Reading Dicey's essay for the first time, I read with the desperation of a man pursued by the furies. I needed to know what he had done, this man who had travelled to the Himalayas for answers; I needed to understand how he had found peace. Endgame was my philosophical Two Girls, One Cup (Villanova, 2007), and I often wished that I had never read the book. Ignorance would have been easier. I would not have to confront myself in the mirror and ask why I was not doing something tangible.

The Unabomber, Theodore Kaczynski, is currently incarcerated in ADX Florence, the federal supermax prison, in Colorado (Oleson, 2016). I saw him there when I toured the facility in 2007, and I did not notice a mirror in his cell. Perhaps he is not permitted to have one. But were Kaczynski to regard himself in a mirror, he would at least see a man whose actions - however contemptible and bizarre they might seem to other people - accorded with his principles (Oleson, 2005). He, at least, would see a man who acted on the strength of his convictions. Who, whatever other demons tear at him, does not have to ask why he saw yet did nothing (Rosenthal, 1964). On the other hand, when I look in the mirror, I must tell my reflection that it is empathy that stays my hand. Or hope. But Kaczynski might call a spade a spade and name it weakness.

Unfortunately, Dicey did not offer a solution. He notes that in India, somehow, Jensen's words simply failed to have the same effect. They no longer burrowed under his skin and lodged in his mind. He no longer felt accused, complicit, and powerless. This, Dicey surmises, may have had something to do with his own general state of wellness. Traveling through India, Dicey was flourishing, which allowed him to read Jensen with a Buddhist-like detachment. Dicey then invokes Robinson Jeffers:

Only tormented persons want truth. Man is like other animals, wants food, success and women, not truth. Only if the mind tortured by some interior tension has despaired of happiness then it hates its life-cage and seeks further (in Dicey, 2016, p. 151).

Jeffers' quote struck me like a fist. Me, who resigned a comfortable government position to accept a university job at half my old salary. The quote is punchy, pithy, and it conveys a big idea. Although I want to challenge it, there is an unavoidable kernel of truth in it. The people I know who are driven most by the truth are tormented. Happily tormented, maybe, like troubadour lovers or like William Blake amid the fires of Hell, observing the "enjoyments of Genius, which to Angels look like torment and insanity" (1794/1994, p. 30). But tormented nevertheless. A friend once told me that I would rather be right than happy. He intended it as criticism, or as a note of concern, but I could not help but hear it as praise. Surely, to be right is to be happy. To be happy but wrong is to be caught up in illusion. 
Dicey's redemption is not a solution. It is the problem. The earth today is stretched to somewhere between four and ten times its carrying capacity (Oleson, 2007a) because men, in their pursuit of wellness, have sought out food, success, and women. Because the world over, they (very reasonably) seek to provide for their families. Because they feel entitled to happiness. Because, so long as it is possible for them to someday own a car, to drink beer, to watch professional sports, to play videogames and peruse internet pornography, and to own the newest generation of smartphone, the irrevocable destruction of the natural world does not matter. Or, perhaps it does matter, but it does not matter enough. It is said that truth is a bitter pill to swallow and that ignorance is bliss. Accordingly, we should not be surprised that most men - who care not for truth - honestly do prefer food, success, and women. On his journey, Dicey was able to distract himself with beauty and experience, to feel connection and humility and awe, and, for a time, this allowed him to squelch the voice of Jensen in his ear. But only for a time.

"No Ship Exists," ends approximately two years later, with Dicey at home, having just read Volume Two of Endgame (Resistance) (Jensen, 2006b) and finding himself, ultimately, unpersuaded by Jensen's call to action. In Volume Two, Dicey was able to discern some of the book's rhetorical devices, to spot the shifts in its register, and to see many of its themes at work. This allowed him to "discard" the book. But Dicey laments that he cannot so easily discard Volume One, The Problem of Civilization (Jensen, 2006a). In fact, in the final sentence of "No Ship Exists," Dicey admits that Jensen still unnerves him with his "simple and terrifying truths" (2016, p. 159). Endgame is a virus of the mind, a seed crystal of cognitive dissonance, and whatever immunity Dicey had obtained in India was short lived. Two years later, he was still wrestling with Jensen's voice in his ear. If he is like me, he still hears it, and asks why his actions do not align with his beliefs. This, of course, marks Dicey as one of those unfortunate souls who - in Robinson Jeffers' words - "seeks further." This same tortured hunger for understanding, however, is precisely what makes William Dicey successful as a writer, and that equips him with insights. It is Dicey's search for truth that made me so curious about the other essays in Mongrel.

\section{What goes on inside is just too fast}

"What Goes on Inside Is Just Too Fast" is a literary essay, a mediation on "the pleasures and frustrations of reading" (Dicey, 2016, p. 163) that - ostensibly - describes three novels which arrive in a wrapped parcel: J.G. Ballard's collection of short stories, War Fever (1990), Nicholson Baker's The Mezzanine (1988), and Charles Willeford's Cockfighter (1972), which Dicey characterizes as "one of the most transgressive books I have ever read. It is also one of the finest" (2016, p. 177)). Dicey does describe these novels, simultaneously careening through a dizzying description of writers: Bellow, Borges, Milton, Nabokov, Updike, and David Foster Wallace. But his purpose is not to review these titles, as such. Rather, it is to examine his own relationship with fiction, and to explore the role of form therein.

One of the reasons that Dicey chose War Fever is because he was intrigued by "Notes Towards a Mental Breakdown," the final short story in the collection, which consists of a single sentence ("A discharged Broadmoor patient compiles 'Notes Towards a Mental Breakdown', recalling his wife's murder, his trial, and exoneration.") in which eighteen of the words are footnoted. Within the footnotes, the account of Dr. Robert Loughlin and the murder of his wife in a Gatwick Airport hotel room, is revealed. It is no coincidence, that Dicey's essay itself contains an abundance of narrative footnotes. Or that his footnotes, themselves, have recursive footnotes. Or that his footnotes include statistics on the text-to-footnote ratio of popular works of literature. Or that he contrasts Renaissance sidenotes as an alternative to Victorian-era footnotes.

I am no stranger to footnotes, myself. When I was in law school, I produced a satirical five-sentence article with the short title, "Footnote Orgy," in which the entirety of Oliver Wendell Holmes' "The Path of the Law" (1897) comprises one of the three footnotes. Another classic article, "Goodbye to Law Reviews" (Rodell, 1937) fills a second note. Unaware of Ballard's story, I was lampooning the law's tendency to subordinate its real arguments within its notes. But I am complicit in this sin. My climate change article (Oleson, 2007a) has 519 footnotes. Some of those 519 footnotes are straightforward citations, an 
exercise in responsible scholarship, but many of them are narrative tangents, epicycles that wheel in complicated Ptolemaic orbits. They are my tacit agreement that "sometimes ... digression is the only way to be thorough" (Dicey, 2016, p. 161).

One of the other reasons that Dicey chose books by Ballard and Baker relates to a curious reading project that he calls "B". In his essay, Dicey describes a feeling that must be common to many serious readers. "I've long sensed that my reading lacks depth, that no matter how many worthy titles I read, I'll only be skimming the surface of things" (2016, p. 171). Dicey's solution to the vexing problem is to read only authors whose surnames begin with the letter B. Of course, this approach does not square with his receipt of Willeford's Cockfighter, but it, he explains, allows him to:

- Impose some limit on the daunting number of books in existence

- Read authors at greater depth

- Read books of differing quality

- Read more for joy and less for utility

- Undertake projects in “B”-world (2016, pp. 171-73).

Each of these rationales is, of course, footnoted and elaborated. However, although Dicey describes the genesis of $B$, he does not detail its procedures in full. How, precisely, does he select among $B$-authored titles? Is there a hierarchy? Does it apply only to fiction? And what about pseudonyms? George Orwell's true name was Eric Blair; Stephen King published as Richard Bachman. And what happens if Dicey should exhaust all $B$ books? Does he then advance to $C$, or is he circumscribed, for life, reading and re-reading, in the closed universe of $B$ ?

Of course, despite what Dicey purports in footnote five (2016, p. 163), the essay is neither about Dicey's interest in narrative footnotes nor about his B project. Instead, the real organizing principle of his essay can be located in footnote three, when Dicey confesses, "I have been disillusioned with fiction for a number of years now ... I could barely read a novel, and if a work of non-fiction edged toward the creative, it annoyed me" (2016, p. 161). Ballard, Baker, and Willeford cannot all be understood in terms of footnotes or the $B$ project, but all of the books can be understood as works, more cognitive than affective, that restored to William Dicey a sense of pleasure in the consumption of fiction.

\section{D'Arcy and I}

In "D'Arcy and I," Dicey extends the literary foundation laid in the previous chapter. He describes the work of his prolific writer-friend, Michael D'Arcy, author of: Bounty's Children (1997), winner of the 1997 Whitbread First Book Award; Litre Park (2000), a John Bruwer mystery); Of Walking on Gravel (2003), an account of a man's $200 \mathrm{~km}$ walk across the Tankwa, characterized by Dicey as "a work of genius" (2016, p. 202); Underwriting (2005), D'Arcy's most personal work, a history of the author in six episodes; Main Road (2008), a 684-page beast of a book, being a biography of South Africa's first highway, and remarkably outselling all of D'Arcy's previous titles; and Eugène (2010) an imagined account of the period that Afrikaans poet and naturalist Eugène Marais spent in London. Superficially, Dicey's essay appears to be a survey of D'Arcy's six titles, but - as in the previous literary essay - there is more at work here.

There are no footnotes. There is one B/W photograph, reproduced from On Walking on Gravel, that resembles, in many respects, Dicey's own photograph of a wire carriage, suspended over a river, from "No Ship Exists." Perhaps it is not so strange that both writers should include photos. Both are Capetonians from farming families; both attended the same school; both studied engineering at UCT and gave it up for writing. More important, however, is the fact that Dicey is D'Arcy's literary executor. Michael D'Arcy disappeared in 2008, naming Dicey as his executor and leaving the preliminary sketch and raw materials for Eugène for Dicey to organize and edit. After Eugène, Dicey intends to publish one final work on D'Arcy's behalf: Split Loyalties.

In several of the footnotes in the previous essay, "What Goes on Inside Is Just Too Fast," Dicey references the poioumenaic novel, Pale Fire (Nabokov, 1962). Pale Fire reproduces poet John Slade's 999-line 
eponymous poem of life and death and loss, sandwiched between a lengthy preface and an overcomplicated commentary by Charles Kinbote, Slade's neighbor and self-appointed editor. In Kinbote's hands, the poem "Pale Fire" becomes a vessel for Kinbote's own narrative: a fantastic story of King Charles II of Zembla, deposed and exiled from his homeland, then pursued from Zembla to America by Gradus, an assassin. In his self-aggrandizing commentary, Kinbote makes clear that his stories of King Charles and Zembla were the true wellspring for Slade's epic poem, and Kinbote's comment on the missing $1000^{\text {th }}$ line claims that Gradus assassinated Slade, mistaking him for Charles. It is a structural novel, and given Dicey's response to Ballard, Baker, and Willeford, it is unsurprising that Pale Fire should reappear in his footnotes. Too bad that Nabokov cannot be accommodated under the $B$ project.

The relationship between Dicey and D'Arcy echoes that of Kinbote and Slade. Like Kinbote, Dicey has inherited the work of an absent colleague. He struggles to distinguish his own work from that of D'Arcy. This is complicated by the fact that Dicey views his missing friend as the superior writer.

I admitted earlier to thinking, somewhat immodestly, that I could have written one or two of D'Arcy's earlier books. At no stage did it cross my mind that I could have written this one. Its control of cadence, tone, tension and mood is exemplary. Like a hyperbolic function tending toward an asymptote, Of Walking on Gravel ramps up its assault on perfection with each turn of the page (p. 202).

This envy is visible again, when he writes, “The only time I've burned with D'Arcy's gemlike flame was when I was writing Borderline, my book about the Orange River. It was a wonderful feeling, that feeling that you're alive in this little corner of the world right now" (Dicey, p. 195). And Dicey could be Kinbote, waxing on about his relationship with Slade, when he lays claim to the intellectual property mined from D'Arcy's notes:

Some of you will have come across allegations that I stole material from D'Arcy for my forthcoming book, The Heart of the Country. Let me assure you that nothing could be further from the truth. Heart is dedicated to D'Arcy: if it is anything, it is a homage to him. As I mention in the afterword, my project grew out of a single brief idea in one of D'Arcy's notebooks: 'Book idea: centre of the country, plot it, go there.' That's it. That's all D'Arcy had to say on the matter. The idea of presenting Heart in two sections, 'The Map' and 'The Territory' (after semanticist Alfred Korzybski's celebrated dictum 'The map is not the territory'): this is my idea... the analysis of what this centre has to say about the country as a whole: all of this is me" (pp. 217-18).

Readers of Pale Fire eventually realize that Charles Kinbote is - or thinks he is - King Charles of Zembla. But if Kinbote is a king, he is king of unreliable narrators. Dicey effectively crowns him as such, naming Kinbote "one of the most extravagantly insane narrators in all of literature" (2016, p; 166). Over the years, Nabokov scholars have proffered many, mutually exclusive, interpretations of the novel (Boyd, 1991). Some believe that Slade invented Kinbote as a literary device and wrote the commentary as well as the poem. There is no Kinbote. Others believe that Kinbote wrote the poem as well as the commentary. There is no Slade. Still others believe that there is no Kinbote and that the commentary was written by Botkin, an insane Russian professor from Slade's college.

In “D'Arcy and I," there is no D'Arcy. D'Arcy's body of work - Bounty's Children, Litre Park, Of Walking on Gravel, Underwriting, Main Road, and Eugène - does not exist. There is only Dicey, who has blurred truth (e.g., Amazon.com suggests that he indeed published a travelogue of the Orange River entitled Borderline) and falsehood, solipsistically blurring the boundaries between fiction (which he had disavowed in his previous essay) and fact. In fact, in one of Mongrel's epigrams, Dicey quotes an interview with Geoff Dyer to make clear that the contested boundary between fiction and nonfiction underlies the whole of Mongrel. "Fiction, nonfiction - the two are bleeding into each other all the time ... [1]f you look at the proportion of made-up stuff in the so-called novels versus the proportion of made-up stuff in the others, I would expect they're pretty much the same" (in Dicey, 2016, p. 9). Dicey makes his intentions even more clear when he quotes David Shields. 
Several years ago I was a member of the nonfiction panel for the National Book Awards. One of the other panelists, disparaging a book I strongly believed should be a finalist, said, 'The writer keeps getting in the way of the story.' What could that possibly mean? The writer getting in the way of the story is the story, is the best story, is the only story" (in Dicey, 2016, p. 9).

In D'Arcy and I," Dicey has proved himself to be an unreliable narrator, although not an unobservant one. He tells lies in order to reveal deeper truths. His Borges-like description of novels - imagined but unwritten - and his observations about the crucible of written work, about the temperament and the perspective that distinguish the real writer from the impersonator - these are Dicey's real objects, clarified and refined through the imagined presence of another.

The three remaining essays in Dicey's collection - "Miss Meat Festival," "South African Pastoral," and "A Story in Which Everyone Looks Bad" - are not literary essays as such. They are less about writing than they are amalgams of journalism, travelogue, sociology, and self-reportage. They feel very South African. The place names, the slang, and the Dutch-stained Afrikaans phrases: these allow Dicey to paint a vivid portrait of life in Cape Town and Ceres. For those who have not visited South Africa, whose limited knowledge of the place is nothing more than a map marker, a litany of $A$ to $Z$ from politics and art (e.g., apartheid, Boer, Coetzee, and on to Zuma), the essays produce the effect actual travel can have. By displacing the reader and making him or her unsettled, Dicey invites his readers to shed their blinders of habituation and to glimpse things freshly.

\section{Miss meat festival}

In "Miss Meat Festival," the opening essay in Mongrel, Dicey and his friend Justin attend a two-day community festival in Calvinia, a sheep-farming town that lies in the Karoo region of the Northern Cape. He describes some of the preparations and the Hantam Festival's events - music, dancing, drinking, and a parade of vintage tractors. Mostly, though, the essay relates to meat and its consumption: wors sausages, endless cuts of lamb, and sheep head all appear. And, naturally enough, some of "Miss Meat Festival" relates to the disconnect between meat as animal and meat as commodity:

[S] uburban meat-eaters ... blank their minds to the reality of what they eat. They buy little red cubes in Woolworths, cook them in wine with sage and tarragon. There's no trace of sinew or bone or carcass, no thought of the living lamb. This is one of the salutary lessons of the festival. You're forced to think about your food (Dicey, 2016, pp. 28-29).

This disconnect is part of the story of industrial agriculture, ably explored elsewhere in Fast Food Nation (Schlosser, 2001), Reefer Madness: Sex, Drugs, and Cheap Labor in the American Black Market (Schlosser, 2003), and The Omnivore's Dilemma (Pollan, 2006). In Dicey's essay, he also draws upon David Foster Wallace's "Consider the Lobster" (2004). The entire second half of Wallace's essay engages the ethical question of whether it is "all right to boil a sentient creature alive just for our gustatory pleasure." After establishing that lobsters do, indeed, feel pain, Wallace called out the readers of Gourmet:

[I]s their refusal to think about any of this the product of actual thought, or is it just that they don't want to think about it? Do they ever think about their reluctance to think about it? After all, isn't being extra aware and attentive and thoughtful about one's food and its overall context part of what distinguishes a real gourmet? (in Dicey, 2016, p. 30).

In large part, however, "Miss Meat Festival" is more ethnographic than dietary. The essay introduces the reader to extreme, eccentric characters such as Jan Abraham de Villiers 'Jakkals' van Wyk, "a tall, looselimbed jackal hunter in his early twenties. He's aggressive, unpredictable and has dead eyes" (Dicey, 2016, p. 21). When Jakkals snatches a lighter from Justin, drops it into his drink, downs the drink and spits the lighter onto the floor, I could not help envisioning a younger version of Irvine Welsh's (1993) notorious hard man, Francis Begbie. Jakkals would probably take pride in the comparison. 
For Dicey, who divides his time between urban Cape Town and a pear farm in Ceres, Calvinia does not appear much different from other towns dotted across the plattelands of the North Cape. Justin, however, is a product of the cosmopolitan south. Readers need only to know that "[h]e'll talk Rodin and Trotsky if you let him" (Dicey, 2016, p. 17) and that he rides a recumbent bicycle for long distances to approximate a reasonable portrait. And Calvinia is different enough from Justin's everyday world to confer the new eyes promised by Proust (1993). Snarky and acerbic, Justin proves an excellent foil to Dicey. During one rant, Justin compares the festival to Clint Eastwood's film version of Midnight in the Garden of Good and Evil (Berendt, 1994), reporting back from Savannah, Georgia to his New York City agent: "This place is fantastic. [1]t's like Gone with the Wind on mescalin. They walk imaginary pets here, Garland, on a fucking leash, all right. And they're all heavily armed and drunk. New York is boring" (in Dicey, 2016, p. 33). In another rant, Justin is particularly distressed by the Mej. Vleisfees (Miss Meat) competition, a different celebration of commodified flesh:

Find me one thing that was beautiful this evening, find me just one thing, in the music, the décor, the dress, the behaviour, the people, even those pretty young things who were there precisely to showcase their beauty. It was a vulgar mockery.... The foul acoustics, the weird dancing, the cathartic drinking, the voyeurism: eat your heart out, David Lynch (pp. 25-26).

It would be easy for Dicey to target the coarse, earthy farmers of Miss Meat Festival and mock them for their vulgarity. But he does not, for two reasons. The first reason is that, beneath the veneer of gonzo journalism, the exaggerated character studies, and the implicit comparisons of meat on the grill and meat on the stage, his essay is actually about another, larger and more poignant, subject. Dicey is deeply interested in conceptions of community, and of a post-apartheid South Africa that struggles to understand what it has become. It is revealed obliquely in his description of a black West African hawking t-shirts at the festival (Dicey, 2016, pp. 36-38) and it is made explicit when Dicey writes:

$[T]$ he meat festival is about farmers taking a break from their farms, coming into town to socialise and promote their products.... Calvinia used to be a nagmaal [Afrikaans for Holy Communion] centre. Four times a year, farmers from the outlying districts would trek into town for communion.... Over the course of a nagmaal weekend, they would see friends, catch up on news, court, get married, baptise children, trade biltong and skins for coffee and tobacco. The institution of nagmaal started to wane about the time the Afrikaners ascended to political power in $1948 \ldots$. I don't wish to make any grand claims, but it's interesting to note that the rise of a festival celebrating Afrikaner culture dovetails with the decline of their political power (2016, pp. 31-32).

The second reason that Dicey does not want to mock the sheep farmers of Calvinia is that he, too, is a farmer, and he, too, wrestles with many of the difficulties faced by the men and women of the Karoo. He describes elements of contemporary agricultural life in his essay, "South African Pastoral."

\section{South African pastoral}

This essay is textbook Dicey. It purports to do one thing (e.g., lead the reader through various innocuous budget items from his farm) but it actually does something quite different (e.g., re-examines South Africa's tangled legacy of colonialism, racism, and slavery). The essay traces the social history of ten accounting entries, including moth-ties and ladders. But the real items of which Dicey tries to take account are not listed under their real names.

For example, when Dicey wrestles with the problem of paternalism, it is listed under social worker. Dicey is well aware that although Buchuland Farm is half his - his possession - the people who labor upon his farm are tied to it in a way that he is not (and never will be). They work, sleep, and on the farm, while Dicey divides his time between Cape Town and Buchuland, entrusting its operation to the hands of a manager. He describes a discussion with a farmer-neighbor who wanted to know what Dicey had done for his workers' Christmas. Dicey tells him that he paid them a one-week bonus and a R250 grocery voucher, hastening to add that he asked the vouchers to specify "no alcohol." But the neighbor dismisses Dicey's solution as ineffective. "Alcoholics are persistent. Turn them away from the counter and they'll 
sell the voucher for cash." (Dicey, 2016, p. 100). The neighbor's solution is to provide his workers with a smaller voucher and R100 worth of meat, at least guaranteeing that the children will get Christmas dinner. Dicey agonizes over the ethics of intervention:

The liberal view would suggest that I pay my employees enough for them to stand on their own two feet and then allow them to do just that. I was raised on liberal axioms, I'm sympathetic to this view. The problem, however, is that most of the time my employees don't stand. They fall over. All in all, I feel that it's better to intervene ... There's no getting around the paternalism involved here, but the likely outcome, if I leave them to their own devices, is just too shattering (2016, pp. 109-110).

Ethnicity underlies many of the issues related to class and power. Dicey recounts a saying among colored employees ("If you've got no debt you've got nothing"), and acknowledges that all of the debt problems he has had on his farm have involved his colored employees, while his Sotho and Xhosa employees exercise consistent financial discipline.

I shrink back when a benevolent farmer puts a meaty hand on my shoulder and shares his racist wisdom: "Kyk, daar's een ding wat iy moet verstaan: die kleurlinge, hulle gun mekaar niks nie.' The coloureds grant one another nothing. A week later, this brutalist sociology helps me understand why I can't persuade a promising worker to go on a forklift-driver course. His colleagues will shun him for trying to better himself. Even his drinking buddies will turn on him, calling him "Witvoet", literally "white foot", a term of abuse for a coloured worker who gets on well with his white boss (p. 112).

Socioeconomic stratification of South Africans by ethnicity, masked as class difference, is further clarified under the business expense of directors' entertainment. The "entertainment" in question is attendance at a farmer's day at a regional wine estate (Solms-Delta). Its proprietor, Neuropsychology Professor Mark Solms, described the challenge of buying a farm. "Jinne, a farm comes with people... I didn't want to buy people... They came with the farm and now I'm responsible for them. It's almost as if I own them" (p. 117, italics mine). When he purchased the land, Solms first met with each of the seven families living there, explained that he hoped to chart a new course with them, and asked what would they like to see happen. "The answer was ... silence. It was excruciating. The atmosphere was terrible. They wouldn't even look at me, they looked at their feet" (in Dicey, 2016, p. 117).

Of course, as a university teacher, I, too, have experienced a version of these sullen, downcast silences. In the classroom, as upon the farm, power differentials make genuine collaboration difficult, perhaps impossible. No matter how egalitarian I might think I am during that first meeting, the reality is that I will eventually assign the students' grades. It is naïve and disingenuous to pretend that the students and I are co-creators of the course.

Solms explains that as soon as the workers realized that he was, indeed, the new boss, they began to misbehave: clocking in late, skipping work on Fridays, stealing trellis poles and pumps. Solms was angry, but instead of reverting to the old way of managing, he followed his training: "If you don't understand something, do nothing. Take your time and get the case history right" (p. 118). Solms brought in archaeologists and historians, at great expense, to understand why he could not communicate with his workers. The researchers, however, laid the problem bare: intergenerational shame and frustration snaked deep into the roots of Solms-Delta farm.

When the historians were done, Solms understood why his employees lacked trust and enthusiasm. "This farm was built by slaves, and their descendants are working here still. They aren't exactly slaves any more, but they're usually not doing this job willingly. They were born on the farm and they feel they have no choice but to work for you. Their attitude is one of resentment and they do the minimum" (in Dicey, 2016, p. 119).

This problem, however, is not a Solms-Delta estate problem. It is a South Africa problem. Later in the essay, Dicey laments his country's systemic mediocrity, its toxic public discourse, and its ever-present 
threat of violence. These are the symptoms of crystallized inequality, of decades of rage and self-loathing, capable of eruption at any time.

I once attended a public reading by J. M. Coetzee, who read from his Booker/Nobel winning novel, Disgrace (1999). It was a powerful reading and I bought the book, but even the reading that I had enjoyed could not prepare me for the interrogation of Disgrace. The book was especially difficult because I could clearly see unattractive aspects of myself in the character of David Lurie: loneliness, arrogance, and pride. In Disgrace, Lurie's academic career is destroyed after his sexual misconduct with a student comes to light. Ignobly, he leaves his university and moves in with his adult lesbian daughter, Lucy, struggling to establish a place for himself in her rural community. But after three armed men attack Lucy's farm, raping her, killing her dogs, and setting Lurie on fire before stealing his car, David and Lucy respond to the trauma in divergent ways. David wants justice, retribution, and revenge. As a reader, I suppose I did, as well. Lurie suspects Petrus, Lucy's polygamous neighbor and employee, of organizing the attack. I urged Lurie to avenge himself. But Lucy, now pregnant, forbids him to do so. Instead, she appears apathetic, even accepting the solution of marrying Petrus and of giving him her farm, in exchange for his protection. I could not accept Lucy's decision because, like her father, I am an overeducated white man from the city, encumbered by ideas of social contract theory and the so-called rule of law. But, because Coetzee is such a virtuoso, I was able to glimpse the world from Lucy's perspective - a vision of kinship ties, compressed by the weight of history - and for that moment, I could understand - even if I could not accept - Lucy's decision. Disgrace is a punishing read, but one that allows me to better appreciate the structural problems on Solms-Delta farm and to sympathize with the dilemmas of William Dicey.

On the face of things, William Dicey doesn't seem so very different from David Lurie, either. He too is an overeducated white man on a farm, surrounded by colored workers who likely regard him with an uneasy mixture of gratitude and resentment. Dicey knows that his position - and that of his employees - is an accident of history, a fluke of moral luck. Indeed, he cites Piketty (2014), noting that the notorious formula $r>g$ means that the rate of return on private capital is greater than the rate of economic growth, which means that money makes money, which means that - in Piketty's words - the past devours the future. Because capital accumulates across generations, wealth inequality is heavily stratified by ethnicity, even in the absence of apartheid. Pretending that opportunity is normally distributed in a neoliberal economy, and praising those with wealth as virtuous and blaming the poor as lazy, incapable, or unfit reminds me of Hume's broadside against the whitewashing of history by invoking the idea of a social contract ratified by universal assent.

Can we seriously say, that a poor peasant or artisan has a free choice to leave his country, when he knows no foreign language or manners, and lives from day to day, by the small wages which he acquires? We may as well assert, that a man, by remaining in a vessel, freely consents to the dominion of the master; though he was carried on board while asleep, and must leap into the ocean and perish, the moment he leaves her" (Hume, 1752/2017).

Dicey owns Buchuland Farm because he is the white son of a white farmer; his employees labor upon the farm because they are the colored children of colored laborers.

So constituted, Dicey is confronted with unenviable choices. In managing his workers, he must choose between a benevolent paternalism and a liberalism that confers them the full dignity of personhood but entails a very real risk of ruin. Unlike his neighbors, who unquestioningly embrace paternalistic behaviors, the question fills Dicey with anxiety and distress. It is not altogether different from the dilemma described in Justice Accused (Cover, 1975). Northern U.S. judges, ordered to return escaped slaves to the South as chattel under the Fugitive Slave Act laws, were confronted with four hard choices: do what they wanted to do; do what they were supposed to do; abdicate the bench; or cheat, pretending to make one decision while actually making another (Oleson, 2007b). Dicey chooses paternalism, convincing himself that he is helping his workers. I suspect that he is helping them, but Dicey is also self-aware enough to admit that owning the farm helps him. And not just in the obvious financial ways. His farm, and his engagement with the workers on his farm, allows him to be "less isolated and oblivious and petty and 
scared and - in a low-level, bourgeois kind of a way - less evil" (2016, p. 121). He reveals himself to be like the sheep farmers of the Karoo, searching for community, striving for a new form of nagmaal.

\section{A story in which everyone looks bad}

All of this - South Africa's legacy of racism and violence and mediocrity and apathy and shame - all of this somehow culminates in "A Story in Which Everyone Looks Bad." The structural conceit of Dicey's essay is simple: it employs fifty numbered sections, like the statutory sections of a penal code. On the surface, the essay could be understood as a murder mystery - one of those thinking man's mysteries that asks not only who but also why. It has sex. It has violence. For added dramatic effect, there is even a murder trial. Underneath the surface, however, the essay is a furious indictment of South Africa's criminal justice apparatus. And beneath that, there is yet another reading that has nothing to do with the homicide or trial, but that - again - poses hard questions about ethnicity, class, stigma, and shame. This final reading is the one most akin to what Dicey said about John Bruwer in Litre Park (D'Arcy, 2000): "[O]ne senses that he's searching not just for a killer, but also for clues to his own past, to his brutal role in the apartheid state" (2016, p. 197).

The first reading of the essay relates the sad story of a murder. The adjective "sad" is redundant, of course, as all murders are sad. In November 2008, "Teffy" a gay man in his 50s, was found murdered in Cape Town. Dicey comes to know the story through his friend, Liam - Teffy's nephew. The story unfolds as a crime procedural with a whiff of intrigue: Teffy's family and friends did not know that he was gay. When forensic evidence ties a young man, Ismail, to the crime scene, Ismail claims to be innocent. Yes, he admits he was there when Teffy was killed, but Ismail insists that Teffy was his friend. Ismail points the finger at his older cousin, Egshaan, who has recently served 18 years in prison.

As the story unravels (and that is the verb for it), punctuated by judicial delays and incompetent counsel, there is contradictory testimony, mental health evidence, and indication that Ismail and Egshaan had gone to Teffy's flat to rob him. Procedural maneuverings eclipse the crime in a pale imitation of Kafka's The Trial (1998): the hearings drag on for 55 months. The reader is left with the impression that Ismail is weak but not evil, a bipolar drug addict, and a hustler who traded sexual favors with Teffy for drug money; on the other hand, Egshaan is a hard man with a gun, a psychopath who boasts to his friends about a murder to which he will never confess. Later, at trial, the sitting judge finds Ismail and Egshaan both guilty of murder, finally sentencing both of the men to 15 years in prison. Dicey's essay left me dimmed, more tired than vindicated, thinking about the enormous waste of both crime and punishment.

What anger I do feel as a reader relates to the system itself. It is a system, and those who work within it cannot help but become inured to the tragedies of criminal justice. They cannot feel the grief of the murder victim's family. They cannot feel the terror of the defendant accused. To do so, day after day, would destroy them.

The horrible thing about all legal officials, even the best, about all judges, magistrates, barristers, detectives, and policemen, is not that they are wicked (some of them are good), not that they are stupid (several of them are quite intelligent), it is simply that they have got used to it. Strictly they do not see the prisoner in the dock; all they see is the usual man in the usual place. They do not see the awful court of judgment; they see only their own workshop (Chesterton, 1909/2011, p. 51).

This is the second reading of "A Story in Which Everyone Looks Bad." Criminal justice is, unavoidably, a system, with all of the failings and limitations of a system, but the existence of a separate justice system for rich and for poor, such as that described in The Divide (Taibbi, 2014), or as described in the final pages of Dicey's essay, is untenable. If the sovereign is going to claim a monopoly on justice, taking vengeance out the hands of the aggrieved and entrusting it to the wisdom of judges, it had better do that job well. And not just for the rich and the powerful. Dicey quotes Liam as condemning the proceedings, "Everyone involved lacks either talent or motivation ... and most lack both. There's no lucidity of thought, no 
intellectual rigour, no desire to walk the extra mile. Come to think of it, there's probably nothing for you to write about but stupidity and laziness" (Dicey, 2016, p. 55). Such stupidity and laziness, which are mere irritants in other spheres of work, become unpardonable evils when they degrade justice and compromise essential liberty interests. When Dicey describes Egshaan's defense attorney, Purker, sputtering, "I put it to you ... I put it to you ... I put it to you" in a vacuous cross-examination (2016, p. 50), I half-smiled. Purker is a buffoon, a hyperbolic character like Jakkals, and it is tempting to dismiss him as a literary clown. But when I reminded myself that Teffy was dead and that Purker was trying to shift suspicion from Egshaan onto Ismail, my smile drained away from my lips. Criminal justice is, unavoidably, a system, but it is one that trades in life and death. There is no excuse for injustice by design. Journalist Steve Bogira has noted that the death penalty and wrongful convictions shape the American public's understandings of miscarriages of justice, but that "justice miscarries every day, by doing precisely what we ask it to (2005, p. 22, italics mine).

Systemic injustice, however, is not restricted to Chicago. In $\$ 38$, Dicey quotes from a 2009 report, noting that in South Africa, $75 \%$ of all serious and violent crimes never make it to court. Of those that do, half are withdrawn by prosecutors, and half of the rest (just $6 \%$ of the total) result in convictions. Dicey describes a broken criminal justice system staffed by illiterate clerks, inexperienced leaders, and precious little appetite for work or accountability. Even the workplace basics of punctuality and performing one's assigned duties are widely absent.

The third reading of "A Story in Which Everyone Looks Bad" extends this analysis and locates it against the backdrop of South Africa's turbulent history of racism and apartheid. When Dicey meets with a former magistrate (who agrees to speak on condition of anonymity), the magistrate confirms that the judicial system is ailing, and ascribes this to a change in attitudes:

Well, at the upper levels - the magistrates and prosecutors and so forth - it's the loss of white experience and the rapid promotion of BEE people who don't yet have the requisite experience. At the lower levels, it's trench warfare. The new clerical employees are almost all black and they're keenly aware of past grievances. When the old coloured staff try to train them, they tell them to fuck off (p. 81).

Dicey realizes his readers might discount the magistrate's observation as the scorn of another disaffected white South African, like the meaty-handed farmer who observed that coloureds grant one another nothing, so he points out that, perhaps unexpectedly, the former magistrate had been a victim of apartheid, not its beneficiary.

The magistrate's diagnosis might initially read like apartheid-era racism, but there is something else at work here. Something buried, but restlessly so, under the South African soil. The magistrate's criticism of the courts reveal the same fissures of frustration that divide Solms-Delta Farm and the same fault lines that makes sense of the horrific home invasion in Coetzee's Disgrace. Poor South Africans did not choose their lot under apartheid; it was foisted upon them. The same is true of rich South Africans, of course, though they have less occasion to complain. This chessboard was set long before any living players were born, and there is no clean way back to an ex ante state. But the poor, who have always been poor, as surely as $r>g$, and whose shame in their poverty has curdled over long years into witvoet culture and anesthetic drinking, will reclaim their dignity through whatever means remain available to them. In an elegant line of poetry, W. H. Auden (1939/2017) renders an ugly truth beautiful: "Those to whom evil is done/Do evil in return."

\section{Conclusion}

In his essay, "South African Pastoral," Dicey describes the many thousands of shards of glass he has discovered upon his property - fragments of green, brown, and clear bottles, bottles of beer and wine and spirits - that reveal the scope (and literally, the depth) of drinking on the Western Cape, like archaeological layers (Dicey, 2016, p. 101). But the alcohol is incidental. What truly lies stratified, in layer 
upon layer, is human exploitation. Dicey acknowledges as much in "A Story in Which Everyone Looks Bad," when he mentions the film, Paradise: Love (Seidl, 2012). In the film, an overweight Austrian woman travels visits a Kenyan beach resort as a sex tourist, "an excruciating study of exploitation running both ways" (Dicey, 2016, p. 80). Similarly, in Disgrace, David Lurie victimizes his student and is victimized in turn. Solms' workers stole from him because he, as a wealthy white outsider, effectively stole from them with the act of purchasing his farm. Dicey struggles with these relationships, too, aching to help but knowing that his interventions create problems as quickly as they solve them.

Upon completing Mongrel, I found myself pondering the idea of nagmaal, of a genuine community gathered to reaffirm itself. The concept of Ubuntu ("a person is a person through other people") alights upon the same idea. That, it seems, might be an antidote to the magistrate's lament, might be a solution to the incompetence of apathy. But community is a rare commodity these days. When Robert Putnam (2000) examined community involvement in the United States, he discovered that civic and community engagement had declined precipitously since the 1950s. He might well have been describing South Africa (or many other industrialized nations). And while the motivating impulse of the Hantam Festival might originate from the right kind of sentiment; that celebration unified only Afrikaners. Dicey did not see a single black South African during the whole festival.

The same phenomenon plays out on a different scale in "No Ship Exists," when Dicey describes his attempt to escape the consequences of Derrick Jensen's (2006a) Endgame. Here, too, the absence of a wider human community facilitates the economic competition that drives climate change. Because the Ghanan men and boys who scavenge the electronics dumps of Agbogbloshie for scrap metal are not known to me, their predicament is not enough to stop me from buying new consumer goods. Because the poor of Bangladesh are not real to me, not in the way that my family and friends are real, the danger that sea level rise poses to them is insufficient to prevent me from living and consuming like an American. I live blithely, ignoring the fact that what I do today degrades the world of the future for my son. Of course, this is madness: if any of these people - Ghanan, Bangladeshi, or from a generation as yet unborn - were to collapse on the street in front of me, I would rush to their aid. But out of sight is out of mind, and as traditional community dwindles, our capacity for redemption through nagmaal dwindles too.

It might not be as obvious, but the same search for authenticity (and the same skepticism about its attainability) drives Dicey's literary essays. When he writes about the $B$ program, he is not proposing a serious solution (after all, one book in three does not satisfy his criteria), but he is raising serious questions about how a modern human being can be literary in a globalizing world where written output expands year after year. And when Dicey proves himself as an unreliable narrator, writing about a Michael D'Arcy who does not exist, it is to reveal something true about writing. These issues, our interconnectedness to one another and our search for authenticity, are the unifying theme of William Dicey's six essays. They are also pressing questions for scholars - readers and writers alike - around the world today.

\section{References}

Auden, W. H. (2017, May 29). September 1, 1939. Retrieved from poets.org website: https://www.poets.org/poetsorg/poem/september-1-1939 (original work published 1939).

Bacon, F. (1985). Essays (J. Pitcher, Ed.). Harmondsworth: Penguin (originally published 1597).

Baker, N. (1988). The mezzanine. New York, NY: Weidenfeld \& Nicholson.

Ballard, J. G. (1990). War fever. London: Collins.

Bastow, S., Dunleavy, P., \& Tinkler, J. (2014). The impact of the social sciences. Los Angeles, CA: SAGE.

Berendt, J. (1994). Midnight in the garden of good and evil. New York, NY: Random House.

Blake, W. (1994). The marriage of heaven and hell: A facsimile. Mineola, NY: Dover (originally published 1794).

Bogira, S. (2005). Courtroom 302: A year behind the scenes in an American criminal courtroom. New York, NY: Alfred A. Knopf.

Boyd, B. (1991). Vladimir Nabokov: The American years. Princeton, NJ: Princeton University Press. 
Braun, V., \& Clarke, V. (2006). Using thematic analysis in psychology. Qualitative Research in Psychology, 3(2), 77-101.

Bryman, A. (1988). Quantity and quality in social research. London: Unwin Hyman.

Chesterton, G. K. (2011). The twelve men. In D. Alquist, J. Pearce, \& A. Mackey (Eds.) In defense of sanity: The best essays of G. K. Chesterton (pp. 48-51) San Francisco, CA: Ignatius Press (originally published 1909).

Coetzee, (1999). Disgrace. London: Secker \& Warburg.

Cover, R. (1975). Justice accused. New Haven, CT: Yale University Press.

D’Arcy, M. (1997). Bounty's children. Cape Town: Kwela Books.

D’Arcy, M. (2000). Litre Park. Cape Town: Kwela Books.

D’Arcy, M. (2003). Of walking on gravel. Cape Town: University of Cape Town Press.

D’Arcy, M. (2005). Underwriting. Cape Town: Kwela Books.

D'Arcy, M. (2008). Main road. London: Secker \& Warburg.

D’Arcy, M. (2010). Eugène. London: Secker \& Warburg.

Dicey, W. (2004). Borderline. Cape Town: Kwela Books.

Dicey, W. (2016). Mongrel: Essays. Cape Town: Uzumi.

Emerson, R. W. (1907). Essays (E. H. L. Turpin, Ed.). New York, NY: Charles E. Merrill (originally published 1841). Retrieved 25 June 2017 from http://www.gutenberg.org/files/16643/16643-h/16643-h.htm

Foot, P. (1967). The problem of abortion and the doctrine of double effect. Oxford Review, 5, 5-15.

Gualtieri, E. (1998). The essay as form: Virginia Woolf and the literary tradition. Textual Practice, 12(1), 4967.

Gutkind, L. (n.d.). What is creative nonfiction? Creative Nonfiction, retrieved 25 June 2017 from http://www.creativenonfiction.org/online-reading/what-creative-nonfiction

Holmes, O. W. (1897). The path of the law. Harvard Law Review, 10, 457-478.

Hume, D. (2017, May 29). Of the original contract. Retrieved from Constitution Society website: http://www.constitution.org/dh/origcont.htm (original work published 1752).

Jensen, D. (2006a). Endgame, volume I: The problem of civilization. New York, NY: Seven Stories Press.

Jensen, D. (2006b). Endgame, volume Il: Resistance. New York, NY: Seven Stories Press.

Kafka, F. (1998). The trial (B. Mitchell, Trans.). New York, NY: Schocken Books.

Lounsberry, B. (1990). The art of fact: Contemporary artists of nonfiction. Westport, CT: Greenwood Press.

De Montaigne, M. (1958). The complete essays of Montaigne (D. Frame, Ed.). Palo Alto, CA: Stanford University Press (original work published 1588).

Nabokov, V. (1962). Pale fire. New York, NY: G. P. Putnam \& Sons.

Oleson (2005). Evil the natural way: The chimerical utopias of Henry David Thoreau and Theodore John Kaczynski. Contemporary Justice Review, 8(2), 211-228.

Oleson (2007a). Drown the world: Imperfect necessity and total cultural revolution. Unbound: Harvard Journal of the Legal Left, 3, 19-104.

Oleson (2007b). The Antigone dilemma: When the paths of law and morality diverge. Cardozo Law Review, 29(2), 669-702.

Oleson (2016). Criminal genius: A Portrait of high-IQ offenders. Oakland, CA: University of California Press.

Paine, T. (1776). Common sense. Philadelphia, PA: W. \& T. Bradford, retrieved 25 June 2017 from http://www.gutenberg.org/files/147/147-h/147-h.htm

Palahniuk, C. (1996). Fight club. New York, NY: W. W. Norton.

Piketty, T. (2014). Capital in the twenty-first century (A. Goldhammer, Trans.). Cambridge, MA: Harvard University Press.

Pollan, M. (2006). The omnivore's dilemma: A natural history of four meals. New York, NY: Penguin.

Proust, M. (1993). In search of lost time, Volume V: The captive and the fugitive (C. K. S. Moncrieff \& T. Kilmartin, Trans., D. J. Enright, Ed.) New York, NY: Modern Library.

Putnam, R. D. (2000). Bowling alone: The collapse and revival of American community. New York, NY: Simon \& Schuster.

Rodell, F. (1937). Farewell to law reviews. Virginia Law Review, 23, 38-44.

Rosenthal, A. M. (1964). Thirty-eight witnesses. New York, NY: McGraw Hill.

Schlosser, E. (2001). Fast food nation. New York, NY: Houghton Mifflin Harcourt. 
Schlosser, E. (2003). Reefer madness: Sex, drugs, and cheap labor in the American black market. New York, NY: Houghton Mifflin Company.

Seidl, U. (2012) Paradise: Love [Motion picture]. Austria: Ulrich Seidl Films.

Swift, J. (1729). A modest proposal. Retrieved 25 June 2017 from http://www.gutenberg.org/files/1080/1080-h/1080-h.htm

Taibbi, M. (2014). The divide. New York, NY: Spiegel \& Grau.

Thoreau, H. D. (1849). On the duty of civil disobedience. Retrieved 25 June 2017 from http://www.gutenberg.org/files/71/71-h/71-h.htm

Villanova, M. (2007). Hungry bitches (aka Two girls, one cup) [Motion picture]. Brazil: MFX Media.

Wachowski, A., \& Wachowski, L. (1999). The matrix [Motion picture]. United States: Warner Brothers.

Wallace, D. F. (2004). Consider the lobster. Gourmet (Aug.), 50-64.

Welsh, I. (1993). Trainspotting. London: Secker \& Warburg.

Willeford, C. (1972). Cockfighter. New York, NY: Crown Publishers. 